БУЖДИГАНЧУК Є.Ю.

\title{
АЛГОРИТМИ ДІЙ ПРАЦІВНИКІВ ПРАВООХОРОННИХ ОРГАНІВ ПІД ЧАС РОЗСЛІДУВАННЯ СУТЕНЕРСТВА, ВЧИНЕНОГО ОРГАНІЗОВАНОЮ ГРУПОЮ
}

Наукова стаття присвячена висвітленню деяких аспектів розслідування сутенерства, вчиненого організованою групою. Розглядаються алгоритми дій працівників правоохоронних органів у процесі розслідування цього кримінального правопорушення.

Наголошено на тому, що слідча ситуація є сукупністю сформованих на певному етапі умов розслідування, що сприймаються, оцінюються і використовуються слідчим для вирішення тактичних задач і досягнення стратегічних задач кримінального провадження. На основі проведеного опитування працівників правоохоронних органів автором зроблено висновок, що фактори, які впливали на те, що розслідувані ними випадки сутенерства, вчиненого організованою групою, залишались нерозкритими, є об'єктивні та суб'єктивні.

На основі вивчення матеріалів судово-слідчої практики авторами було сформульовано ситуації, які можуть виникнути на початковому етапі розслідування сутенерства, вчиненого організованою групою: надійшла інформація про заняття сутенерством, зібрано матеріальні та особистісні сліди кримінального правопорушення, підозрювані відсутні (23\%); надійшла інформація про заняття сутенерством, зібрано матеріальні та особистісні сліди кримінального правопорушення, пред'явлено підозру, особа йде на співпрацю зі слідством (11\%); надійшла інформація про заняття сутенерством, зібрано матеріальні та особистісні сліди кримінального правопорушення, пред’явлено підозру, особа не співпрацює зі слідством (29\%); надійшла інформація про заняття сутенерством, зібрано матеріальні та особистісні сліди кримінального правопорушення, підозри пред'явлено членам організованої групи, один із них співпрацює зі слідством (13\%); надійшла інформація про заняття сутенерством, зібрано матеріальні та особистісні сліди кримінального правопорушення, підозри пред’явлено членам організованої групи, зі слідством жоден із них не співпрацює (24\%).

Визначено, що для вирішення визначених ситуацій працівники Національної поліції України мають здійснити низку заходів, які акумулюються в певному порядку. Тобто відповідно до визначених типових слідчих ситуацій розслідування авторами було наведено типові алгоритми дій працівників правоохоронних органів.

Ключові слова: організована група, проституція, сутенерство, тактичне забезпечення, слідча (розшукова) дія, типова слідча ситуачія.

The scientific article is dedicated to covering some aspects of the pimping investigation by an organized group. The algorithms of actions of law enforcement agencies in the investigation of this criminal offense are considered.

It is emphasized that the investigative situation is a set of conditions at a certain stage, which are perceived, evaluated and used by the investigator to solve tactical tasks and achieve the strategic objectives of criminal proceedings. Based on a survey conducted by law enforcement officials, the author concludes that the factors that influenced the cases of pimping investigated by an organized group remained undisclosed are objective and subjective.

Based on the study of the materials of the judicial investigative practice, the authors have formulated the following situations, which may arise at the initial stage of the investigation of pimping committed by an organized group: information was received on

(C) БУЖДИГАНЧУК Є.Ю. - здобувач (ПрАТ «ВНЗ «Міжрегіональна Академія управління 
pimping, material and personal traces of the criminal offense were collected, suspected $\%$ missing; information on pimping was received, material and personal traces of the criminal offense were collected, suspicion was raised, the person was cooperating with the investigation (11\%); information on pimping was received, material and personal traces of the criminal offense were collected, suspicion was raised, the person did not cooperate with the investigation (29\%); information on pimping was received, material and personal traces of the criminal offense were collected, suspicions were presented to members of an organized group, one of them cooperates with the investigation (13\%); information on pimping was received, material and personal traces of the criminal offense were collected, suspicions were presented to members of an organized group, none of them cooperating with the investigation $(24 \%)$.

It is determined that in order to solve certain situations, the National Police of Ukraine must carry out a number of measures that accumulate in a certain order. That is, according to certain typical investigative situations of investigation, the authors provided typical algorithms of actions of law enforcement officers.

Key words: organized group, prostitution, pimping, producing for identification, investigative (search) action, typical investigative situation.

Вступ. Послідовність дій працівників правоохоронних органів має відбуватись у певному алгоритмі. Це робить їх діяльність більш збалансованою та ефективною. Адже не потрібно витрачати зайвий час на вигадування наступних кроків, які вже давно знайдені. Зрозуміло, що імпровізація також має бути, але злагоджені порядки дій зажди доречно мати під рукою. У зв'язку з цим виникає потреба у створенні певної системи типових слідчих ситуацій, які зможуть алгоритмізувати процес розслідування сутенерства, вчиненого організованою групою.

Дослідженням типових слідчих ситуацій під час розслідування окремих кримінальних правопорушень займалися такі відомі науковці, як В.П. Бахін, Р.С. Бєлкін, В.К. Весельський, А.В. Дулов, А.В. Іщенко, О.Н. Колесніченко, В.О. Коновалова, В.С. Кузьмічов, С.Д. Лук'янчиков, М.І. Порубов, М.В. Салтевський, Р.Л. Степанюк, К.О. Чаплинський, Л.Д. Удалова, В.Ю. Шепітько, М.П. Яблоков та інші. Але варто зазначити, що наше дослідження є комплексним підходом до визначення типових слідчих ситуацій розслідування сутенерства, вчиненого організованою групою.

Постановка завдання. Метою статті є визначити алгоритми дій працівників правоохоронних органів у процесі розслідування сутенерства, вчиненого організованою групою.

Результати дослідження. Стосовно визначення досліджуваної наукової категорії ми підтримуємо позицію Л.Я. Драпкіна, який визначив, що слідча ситуація - це динамічна інформаційна система, елементами якої $є$ істотні ознаки й властивості обставин, що мають значення в кримінальній справі, зв'язки, відносини між ними, а також учасниками процесу розслідування, що настали, і передбачувані результати дій сторін [1, с. 28]. Тобто слідча ситуація з огляду на прив'язку до початкового етапу розслідування буде виступати базисом для проведення початкових слідчих (розшукових) та інших дій.

3 огляду на це необхідно наголосити на тому, що ситуаційні особливості розслідування сутенерства, вчиненого організованою групою, відбивають здебільшого типові ситуації, що пов'язані з діями саме цієї групи групи. Тому ми підтримуємо позицію С.А. Циркуна, який за основу їх класифікації взяв спосіб вчинення злочину. Зокрема, за способом розміщення науковець виділяє місця розпусти, що розміщуються в житловому секторі, та ті, які розміщуються поза житловим сектором. За способом прийому замовлень він виокремлює місця, в яких: а) замовлення бере адміністратор місця надання послуг інтимного характеру (умовно кажучи, резидент злочинної організації); б) замовлення приймає будь-яка 3 повій; в) замовлення приймає спеціально залучений оператор. За видом послуг, що надаються, місця для заняття проституцією виокремлюються такі: 3 наданням традиційних сексуальних послуг і місця 3 наданням нетрадиційних послуг сексуального характеру. За механізмом підбору осіб, які займаються проституцією, місця розпусти поділяються: 3 принципом добровільної вербування; пов'язані із залученням до проституції з елементами примушування або обману [9, с. 11]

Своєю чергою, В.О. Лазарєв на основі аналізу матеріалів судово-слідчої практики визначив такі типові слідчі ситуації, які виникають пі час розслідування втягнення неповнолітнього в заняття проституцією: а) особа, яка втягнула неповнолітнього в заняття проституцією, відома, $\epsilon$ 
достатні фактичні дані, які свідчать про конкретні обставини злочину та ії̈ причетності до нього $19 \%$; б) злочинець (сутенер) відомий, але замало доказів для повідомлення йому про підозру 47\%; в) особа, яка втягнула неповнолітнього в заняття проституцією, відома, наявні матеріальні сліди й очевидці злочину, але вона переховується від слідства й суду - $18 \%$; г) наявний факт втягнення неповнолітнього в заняття проституцією, але відсутні матеріальні сліди й очевидці злочину, особу злочинця не встановлено - $16 \%$ [4, с. 111].

М.В. Куратченко стосовно початкового етапу розслідування сутенерства та втягнення особи в заняття проституцією наголошував на існуванні таких типових слідчих ситуацій: 1) злочинець (сутенер, повія) відомий, є достатні фактичні дані, які свідчать про конкретні обставини кримінального правопорушення та його причетність до нього; 2) виявлено факт здійснення сутенерства чи втягнення особи в заняття проституцією, злочинець відомий, але доказів для повідомлення про підозру замало; 3) злочинець (сутенер, повія) відомий, наявні матеріальні сліди злочину й очевидці злочинної події, але він переховується від слідства та суду; 4) злочинець невідомий, відсутні матеріальні сліди та очевидці злочину [3, с. 92].

Зі свого боку, К.Ю. Назаренко на початковому етапі розслідування створення та утримання місць розпусти визначила такі ситуації: а) злочинець відомий, є достатні фактичні дані, що свідчать про конкретні обставини злочину - 24\%; б) злочинець відомий, але доказів замало для повідомлення про підозру - 48\%; в) злочинець відомий, але він переховується від слідства і суду $-16 \%$; г) злочинець невідомий $-1 \%[6$, с. $83-84]$.

На основі вивчення матеріалів судово-слідчої практики нами було сформульовано ситуаціï, які можуть виникнути на початковому етапі розслідування сутенерства, вчиненого організованою групою:

- надійшла інформація про заняття сутенерством, зібрано матеріальні та особистісні сліди кримінального правопорушення, підозрювані відсутні (23\%);

- надійшла інформація про заняття сутенерством, зібрано матеріальні та особистісні сліди кримінального правопорушення, пред’явлено підозру, особа йде на співпрацю зі слідством (11\%);

- надійшла інформація про заняття сутенерством, зібрано матеріальні та особистісні сліди кримінального правопорушення, пред’явлено підозру, особа не співпрацює зі слідством (29\%);

- надійшла інформація про заняття сутенерством, зібрано матеріальні та особистісні сліди кримінального правопорушення, підозри пред'явлено членам організованої групи, один 3 них співпрацює зі слідством (13\%);

- надійшла інформація про заняття сутенерством, зібрано матеріальні та особистісні сліди кримінального правопорушення, підозри пред’явлено членам організованої групи, зі слідством жоден із них не співпрацює (24\%).

Для вирішення визначених ситуацій працівники Національної поліції України мають здійснити низку заходів, які акумулюються в певному порядку. Окремі науковці алгоритм дій слідчого в розслідуванні насильницьких злочинів визначають таким чином:

- аналіз наявної інформації;

- оцінка вихідної слідчої ситуації,

- висунення версій за фактичними та ймовірними обставинами подій;

- постановка тактичних завдань і планування розслідування;

- проведення окремих слідчих (розшукових) дій, негласних слідчих (розшукових) дій та тактичних операцій із перевірки висунутих версій [2, с. 118-119].

На нашу думку, сукупність слідчих (розшукових) дій, негласних слідчих (розшукових) дій та тактичних операцій має найбільш важливе значення при розслідуванні сутенерства, вчиненого організованою групою. Оскільки в наведеному випадку найбільш вагомим є якомога швидший збір інформації про кримінальне правопорушення.

У першій ситуації головним завданням розслідування буде виявлення осіб, причетних до вчинення сутенерства, а також їх зв'язків. Для цього проводяться окремі процесуальні дії, зокрема:

- огляд місця надання послуг інтимного характеру;

- допити повій та свідків події;

- розшук сутенера по «гарячих» слідах;

- збір відеозаписів із камер зовнішнього спостереження закладів, що знаходяться поблизу;

- призначення і проведення експертиз.

3 приводу розшуку злочинів ми підтримуємо думку В.О. Малярової, яка включає послідовне рішення таких завдань: 
- виявлення джерел інформації про ознаки шуканого злочинця;

- побудова гіпотетичної моделі злочинця (шуканої особи) та встановлення його належності до: широкої сукупності (класу) осіб за загальними ознаками; вузької сукупності (групи) осіб за окремими ознаками;

- встановлення обмеженої, кількісно визначеної групи осіб, що перевіряються;

- встановлення особи, що перевіряється, тобто особи, яка згідно з обставинами кримінального провадження може бути шуканим злочинцем, та за необхідності отримання від неї зразків для експертизи згідно зі ст. 245 КПК України;

- ідентифікація конкретної особи;

- встановлення шуканого злочинця [5, с. 131].

Так, гр. М., володіючи якостями лідера, вирішила для заняття сутенерством створити в м. Одесі організовану групу учасників, яку об’єднати єдиним планом із розподілом функцій кожного з учасників групи. У подальшому гр. М. залучила до групи свого співмешканця гр. Д., а також безпосередніх виконавців. У процесі злочинної діяльності гр. М. та гр. Д. здійснювали загальне керівництво організованою групою, розробили єдиний план, схему і способи вчинення злочинів, довівши ці дані до відома всіх учасників групи, підшукали та залучили до вчинення злочинів безпосередніх виконавців злочинних дій, брали безпосередню участь у вчиненні злочинів; встановили в групі певну ієрархію, порядок підпорядкованості членів групи лідерам, розподіляли обов'язки між учасниками групи; спрямували, об'єднали і скоординували зусилля співучасників на вчинення злочину, проводили їх інструктаж щодо виконання ними відповідних злочинних дій, вживали заходи щодо конспірації своїх дій, розподіляли гроші, здобуті злочинним шляхом, забезпечували фінансування злочинних дій учасників організованої групи. Згідно з розробленим гр. М. злочинним планом, учасники діяли за двома схемами: 1) організація зайняття проституцією через рекламування послуг повій за допомогою мережі Інтернет: особа, яка бажає замовити послуги повій, заходить на сайт «mister-x.org», дошку об'яв «UKRGO», де розміщуються фотографії повій та вказаний номер телефону для зв'язку. Після обрання повії клієнт телефонує за номером, обговорює (нібито з дівчиною, а насправді з гр М.) види, вартість послуг та призначає зустріч на вибраному ним чи повією місті. При зустрічі попередньо передає повії кошти, які остання після надання інтимних послуг клієнту за допомогою платіжного терміналу поповнює рахунок банківської картки, відкритої в ПриватБанку, чи особисто передає; 2) організація зайняття проституцією в публічно доступних місцях вулицях м. Одеси: повї̈ стоять на узбіччі рогу вулиць Заславського та Арнаутської в м. Одесі, де пропонують інтимні послуги стороннім особам за матеріальну винагороду. Під час виявлення фактів за другою схемою правоохоронці й почали загальне розслідування вчиненого кримінального правопорушення. Була проведена вся сукупність слідчих (розшукових) дій та інших заходів [8].

Друга слідча ситуація характерна для сутенерства, вчиненого відкрито або за певної кількості свідків. У цьому разі вже на початковому етапі розслідування встановлено особу підозрюваного, яка йде на співпрацю зі слідством. Відповідно до цих умов можливими є такі дії щодо розслідування правопорушення:

- огляд місця події;

- допит свідків;

- призначення судових експертиз;

- виявлення та забезпечення збереження джерел доказів, що включає бесіди, опитування, ОМП, допит, особистий обшук, обшук за місцем проживання та ін.

Третя ситуація характеризується тим, що надійшла інформація про заняття сутенерством, зібрано матеріальні та особистісні сліди кримінального правопорушення, пред'явлено підозру, але особа не співпрацює зі слідством. Вивченням кримінальних проваджень встановлено, що на початковому етапу розслідування кримінального правопорушення в такій ситуації доцільно проводити такі дії:

- допити повій;

- допити клієнтів;

- обшуки підозрюваних під час затримання;

- обшуки за місцем проживання підозрюваного;

- призначення експертиз;

- негласні слідчі (розшукові) дії та оперативно-розшукові заходи, націлені на встановлення співучасників злочину. 
Так, гр. Є. запропонував гр. Ї. увійти до складу злочинної групи з метою спільного зайняття сутенерством та повідомив йому про розроблений ним план злочинних дій щодо забезпечення діяльності з надання сексуальних послуг особами жіночої статі. Реалізуючи їхній спільний злочинний умисел, гр. С., розуміючи, що для організації забезпечення такої незаконної діяльності необхідно підібрати інших осіб як виконавців, які б здійснювали контроль за діяльністю осіб, що надають сексуальні послуги, займались пошуком та підбором приміщень для надання оплатних послуг сексуального характеру, осіб жіночої статі для зайняття проституцією, доставкою повій до місць надання сексуальних послуг та до клієнтів, забезпечення їх охороною, останній спільно з іншими учасниками в різний період часу підібрали для участі в злочинній групі та залучили до зазначеної протиправної діяльності інших осіб. Організована злочинна група характеризувалась таким чином: попередня організованість в спільне об'єднання, про що свідчить розроблений та ухвалений учасниками групи план вчинення злочинної діяльності, чіткий розподіл ролей між учасниками групи, наявність організатора, прикриття своєї діяльності; стійкість злочинного об'єднання, що відбилося на стабільності групи, про що свідчить тривалість, системність та детальна організація функціонування групи, наявність необхідних для функціонування групи фінансових можливостей, а також згуртованості групи, що засвідчують міцні внутрішні зв'язки між учасниками групи, встановлені загальні правила поведінки, єдиний план злочинних дій та усвідомлення кожним з учасників факту об'єднання $з$ іншими особами у групу для досягнення єдиного злочинного результату; «спеціалізація» злочинної діяльності учасників організованої групи, яка виражалась у сутенерстві; тривалість існування 3 початку 2016 року по лютий 2017 року. Під час розслідування було організовано проведення негласних слідчих (розшукових) дій та оперативно-розшукових заходів, спрямованих на встановлення співучасників злочину. Після визначення більшої кількості підозрюваних одночасні допити раніше допитаних осіб почали давати результати [7].

У четвертій ситуації характерним є те, що підозри пред’явлено членам організованої групи, а один із них співпрацює зі слідством. Тому, крім вищезазначених, додається комплекс заходів із реалізації тактичної операції з виявлення свідків та очевидців цього кримінального правопорушення. Крім того, необхідно під час проведення окремих слідчих (розшукових) дій доводити до відома інших членів організованої групи про відому слідству інформацію, застосовуючи тактичний прийом «збільшення уявлення про поінформованість слідчого».

В останній ситуації треба провести такий комплекс слідчих (розшукових) дій та процесуальних заходів:

- допити членів організованої групи;

- обшуки за місцем мешкання усіх членів організованої групи;

- встановлення та допит свідків;

- призначення та проведення експертиз по виявленим речовим доказам.

Висновки. Констатуючи вищенаведене, необхідно зазначити, що на основі вивчення матеріалів судово-слідчої практики нами було сформульовано ситуації, які можуть виникнути на початковому етапі розслідування сутенерства, вчиненого організованою групою: надійшла інформація про заняття сутенерством, зібрано матеріальні та особистісні сліди кримінального правопорушення, підозрювані відсутні (23\%); надійшла інформація про заняття сутенерством, зібрано матеріальні та особистісні сліди кримінального правопорушення, пред'явлено підозру, особа йде на співпрацю зі слідством (11\%); надійшла інформація про заняття сутенерством, зібрано матеріальні та особистісні сліди кримінального правопорушення, пред'явлено підозру, особа не співпрацює зі слідством (29\%); надійшла інформація про заняття сутенерством, зібрано матеріальні та особистісні сліди кримінального правопорушення, підозри пред’явлено членам організованої групи, один 3 них співпрацює зі слідством (13\%); надійшла інформація про заняття сутенерством, зібрано матеріальні та особистісні сліди кримінального правопорушення, підозри пред’явлено членам організованої групи, зі слідством жоден із них не співпрацює (24\%). Відповідно до визначених ситуацій нами були наведені типові алгоритми дій працівників правоохоронних органів.

\section{Список використаних джерел:}

1. Драпкин Л.Я. Понятие и классификация следственных ситуаций. Следственные ситуации и раскрытие преступлений : сборник науч. тр. 1975. Вып. 41. С. $27-29$.

2. Жерж Н.А. Слідчі ситуації та типові криміналістичні версії щодо особи злочинця при розслідуванні окремих насильницьких злочинів / Н.А. Жерж, М.Є. Дирдін. Науковий вісник Ужгородського начіонального університету. 2015. Серія ПРАВО. Випуск 32. Том 3. С. 117-121. 
3. Куратченко М.В. Особливості взаємодії слідчих та оперативних підрозділів при розслідуванні сутенерства та втягнення особи в заняття проституцією. Науковий вісник Дніпропетровського держ. ун-ту внутрішніх справ : збірник наук. праць. 2017. № 2. С. 227-234.

4. Лазарев В.А. Типичные следственные ситуации расследования вовлечения несовершеннолетнего в занятие проституции и сутенерстве. Международный научно-практический журнал «Право и Закон». 2017. № 3. С. 107-112.

5. Малярова В.О. Тактико-криміналістичні та процесуальні основи пошуку та затримання злочинця : дис. ... канд. юрид. наук : 12.00.09 / Нац. ун-т внутр. справ. Харків, 2005. 238 с.

6. Назаренко К.Ю. Методика розслідування злочинів, пов'язаних зі створенням або утриманням місць розпусти і звідництвом : монографія / Дніпро : Дніпроп. держ. ун-т внутр. справ; Ліра ЛТД, 2017. 190 c.

7. Справа № 361/3876/17, Архів Броварського міськрайонного суду Київської обл., 2017 р.

8. Справа № 522/13846/15-к, Архів Приморського районного суду м. Одеси, 2015 р.

9. Цыркун С.А. Выявление и расследование преступлений, связанных с содержанием притонов для занятия проституцией : автореф. дис. ... канд. юрид. наук. Москва : Московская государственная юридическая академия, 2004. $21 \mathrm{c.}$

УДК $343.98: 343.131$

DOI https://doi.org/10.32844/2618-1258.2019.5-1.41

ЄФІМОВ М.М.

\section{ДЕЯКІ АСПЕКТИ ПІЗНАВАЛЬНОЇ ДІЯЛЬНОСТІ СЛІДЧОГО, ЩО ВИКЛИКАЮТЬ СУМНІВИ СТОСОВНО ОСУДНОСТІ ОСОБИ ПІД ЧАС РОЗСЛІДУВАННЯ ЗЛОЧИНІВ ПРОТИ МОРАЛЬНОСТІ}

Наукова стаття присвячена висвітленню деяких аспектів розслідування злочинів проти моральності. Досліджено деякі аспекти пізнавальної діяльності слідчого, під час якої виникають сумніви щодо осудності особи, яка вчинила кримінальне правопорушення. Доведено, що сумнів щодо осудності особи виникає не лише внаслідок отримання документів про наявність в особи психічного захворювання, а також під час безпосереднього спостерігання слідчим емоційного стану особи, ії способу мислення, рівня розвитку інтелекту, пам'яті, мовлення.

Встановлено, що питання щодо визначення віку особи, а також первісної кваліфікації злочинних діянь на початку досудового розслідування, як правило, не викликають у слідчих складнощів, то встановлення осудності особи потребує спеціальних знань та практичних навичок. 3'ясовано, що пізнавальна діяльність слідчого у процесі розслідування злочинів проти моральності здебільшого досліджується науковцями з позиції змоги побудувати версії злочину, встановити зв'язки між окремими фактами події з метою підтвердити чи, навпаки, спростувати ці версії, встановити особу винного, а сама особа винного досліджується через вивчення iіi способу життя. Але, на нашу думку, слідчий має змогу і повинен використовувати такий пізнавальний інструмент, як власне спостереження за поведінкою особи, включаючи ії темперамент, спосіб мислення, рівень інтелекту тощо.

Наголошується на тому, що емоційний стан підозрюваного, порушення пам'яті та інтелекту, дефекти мовлення підозрюваного, що виявляються під час проведення з ним слідчих (розшукових) дій при розслідуванні злочинів проти моральності, мають сприйматися слідчим у взаємозв'язку, взаємозумовленості та оцінюватися не лише з точки зору лінії захисту підозрюваного, а також ознак, що можуть вказувати на психічні розлади особи. Поряд з іншими добутими під час досудового

ЄФІМОВ М.М. - кандидат юридичних наук, доцент, доцент кафедри криміналістики, судової медицини та психіатрії (Дніпропетровський державний університет внутрішніх справ) 